\title{
In Vitro Selection of Salt-Tolerant Olive Clones
}

\author{
J. Troncoso, J. Liñán, M. Cantos, J.L. García and A. Troncoso \\ Instituto de Recursos Naturales y Agrobiología de Sevilla (CSIC) \\ Avda. Reina Mercedes 10, 41012 Sevilla (Spain).
}

Keywords: olive, salt tolerance, in vitro selection, embryos

\begin{abstract}
Zygotic mature olive embryos from olive plants growing in the World Olive Plant Collection of Cordoba (Spain) and in high salinity marshes, were cultured in vitro on $1 / 3$ MS medium with different $\mathrm{NaCl}$ concentrations: $0,4,6$ and $8 \mathrm{gL}^{-1}(0,68.4,102.6$ and $136.9 \mathrm{mM}$ respectively).

Close to $100 \%$ of the embryos cultured in control medium formed normal seedlings, showing good growth. The addition of $\mathrm{NaCl}$ to the medium decreased these parameters but different responses were observed due to the natural genetic variability of the embryos. Thus, some embryos showed low ability to grow at low saline concentrations while others, even from the same mother plant, were able to germinate and grow well at salt concentrations of $8 \mathrm{gL}^{-1}$. But, in general, embryos from plants growing in saline areas, germinated better in salt than those from cultivated olive trees. Explants from low and high salt tolerant seedlings were propagated in vitro by subculturing in media without salt and the clonal lines obtained were tested for their salt tolerance by culturing in vitro on 1/3 MS media with different $\mathrm{NaCl}$ concentrations: $0,2,4,6,8,10$ and $12 \mathrm{gL}^{-1}(0,34.2,68.4,102.6,136.9,171.1$ and $205.3 \mathrm{mM}$ respectively).

A correspondence between the tolerance observed for the original seedlings and the plantlets obtained from them was found.

Plants with low ability to grow in low salt concentration (low salt tolerant) and plants which could grow at $12 \mathrm{gL}^{-1}$ (high salt tolerant) were selected to be tested in outside conditions.
\end{abstract}

\section{INTRODUCTION}

Seed germination is the most common method for plant propagation and a good way to maintain, or even increase plant biodiversity. Seed germination was used by Fenician, Greek and Roman colonisers to spread oliviculture throughout the Mediterranean Basin. Later, when farmers became interested in olive plant selection, agamic propagation methods were used. The current increase of breeding works has renewed the interest in seed germination.

Olive seed, covered by the stony endocarp, needs much time to germinate and does so in a low proportion (Scaramuzzi, 1963; Bini \& Bellini, 1975; Diamantoglou \& Mitrakos, 1979) which is a handicap for breeding works development. Some authors (Lagarda et al., 1983; Crisosto \& Sutter, 1985) indicated that the woody endocarp is a mechanical barrier for germination, and Mitrakos \& Diamantoglou, (1984) considered that it also hindered the gas and liquid exchange. Thus, removal of the stony endocarp accelerates germination, and enhances the percentage of germinated seeds (SotomayorLeón \& Caballero, 1990; Lambardi et al., 1994). Even better results are attained by the in vitro culture of isolated embryos (Troncoso et al., 1991; Sarmiento et al., 1994; Voyiatzis \& Pritsa, 1994; Acebedo et al., 1997), particularly at low temperature (Voyiatzis, 1995), showing its potential for use in olive breeding works (Troncoso,1994). 
The in vitro culture of isolated embryos allows to know in a short time their tolerance to salt without any interference of soil or climate (Ben-Hayyim et al., 1989). Nevertheless, it is necessary to check the ex vitro behaviour of the plants after the in vitro selection (Skene \& Barlass, 1988).

The aim of this work is to know the effect of $\mathrm{NaCl}$ in the medium on the in vitro development of isolated olive embryos in order to see whether this system can be used for the obtaining of salt tolerant olive plants.

\section{MATERIAL AND METHODS}

Olive fruit were harvested at the end of July from 4 different plants: one of cv. "Galego", and other one of cv. "Lechín" (both cultivated in the World Olive Plant Collection of Cordoba, Spain); other plant growing in "Raboconejo" in the River Odiel Marsh (Huelva, Spain), and other in "Lagolargo" in the Cadiz Bay Marsh (Cadiz, Spain). These last two areas are harsh salines marshes and consequently their olive plants are growing in high saline conditions (Cantos et al, 2002). Mature olive embryos were isolated as described by Acebedo et al. (1997) and placed individually in test tubes (21x $150 \mathrm{~mm}$ ) with $10 \mathrm{cc}$ of the following culture media: 1/3 strength MS (Murashige and Skoog, 1962) with $5 \mathrm{gL}^{-1}$ agar (control medium), and respectively the control medium plus 4,6 , and $8 \mathrm{gL}^{-1}$, equivalent to 68,102 , and $136 \mathrm{mM}$ of $\mathrm{NaCl}$. The test tubes containing the embryos, were covered with plastic caps, sealed with parafilm, and placed in a growth chamber at $23{ }^{\circ} \mathrm{C}, 16 \mathrm{~h}$. photoperiod, and $30 \mu \mathrm{Em}^{-2} \mathrm{~s}^{-1}$ of light intensity. Forty embryos per saline treatment and mother plant, 640 in total, were used for the experiment. Initial growth of the axis (emergence of hypocotyl and root) and opening and green colour of cotyledons was regarded as germination. Development of stem and leaves (aerial part) and radicular system (a long pivotant root) was regarded as seedling formation.

The seedling of each mother plant with better growth in the $8 \mathrm{gL}^{-1} \mathrm{NaCl}$ medium were chosen as salt tolerant and nominated respectively as G-8 (from cv "Galego"), L-8 (from cv "Lechín"), both from Plant Collection of Cordoba (Spain) and RC-8 (from "Raboconejo" olive plant) and LL-8 (from "Lagolargo" olive plant) from the high salinity marshes. Uninodal, one $\mathrm{cm}$. length, explants from the selected seedlings were in vitro propagated several times on OM (Rugini, 1986) medium without $\mathrm{NaCl}$, to attain enough number of explants. Similar explants were prepared from all the seedlings germinated in the control $\left(0 \mathrm{gL}^{-1} \mathrm{NaCl}\right)$ germination medium (no selected seedlings) and grouped as $\mathrm{G}-0$ (seedlings from "Galego" embryos), L-0 (seedlings from "Lechín" embryos), RC-0 (seedlings from "Raboconejo" embryos) and LL-0 (seedlings from "Lagolargo" embryos).

168 uninodal explants ( 24 per $\mathrm{NaCl}$ treatment) of each selected and non selected lines (8 lines), 1344 explants in total, were cultivated on OM medium with respectively addition of $0,2,4,6,8,10 \mathrm{y} 12 \mathrm{gL}^{-1}$ of $\mathrm{NaCl}$, equivalent to $0,34.2,68.4,102.6,136.9$, 171.1 and $205.3 \mathrm{mM}$. In vitro explant survival and growth were measure to define their salt tolerance.

Nutritive status of both in vitro seedlings and explants was controlled. Nitrogen was determined according to Jackson (1962), and the other elements after calcination (Wallinga et al., 1995) by ICP-OES. Quality control samples from the IPE-WEPAL program (Houba et al., 1996) were also compared with those results deviating less than $10 \%$ from certified values.

Statistical significance was determined using the Student $t$ test. 


\section{RESULTS AND DISCUSSION}

The in vitro development of the isolated olive embryos can be divided in two phases: i) germination, defined by the emergence of the axis (hypocotyl and root primordial) and the opening and greening of cotyledons, and ii) seedling formation, with the development of stem, leaves and roots. Table 1 shows the influence of $\mathrm{NaCl}$ concentrations on the two phases. There was a very high percentage $(100 \%)$ of germination when the embryos were cultured in the control medium without $\mathrm{NaCl}$. These results agree with those of Troncoso et al. (1991; 1998), Voyiatzis \& Pritsa (1994), and Voyiatzis (1995), and indicated the good behaviour of the olive embryo when cultured in vitro. Additions of $\mathrm{NaCl}$ to the nutritive medium until $6 \mathrm{gL}^{-1} \mathrm{NaCl}$ did not significantly change the level of embryo germination, showing its tolerance to salt. Uniyal \& Nautiyal (1998) had observed a higher salt-tolerance of the seed during germination than during seedling development. This behaviour was related to the presence in the germinating seed of specific proteins (Blackman et al., 1991; Ried \& Walker-Simmons, 1993) and also to the expression of specific genes (Thomas, 1993). Additions of $8 \mathrm{gL}^{-1}$ of $\mathrm{NaCl}$ to the medium significantly decreased the level of germination, establishing statistical differences with all the other treatments.

Since this $100 \%$ of germination was obtained in a culture chamber at $23{ }^{\circ} \mathrm{C}$, there was not the negative effect of higher temperature reported by Mitrakos \& Diamantoglou (1984).

Seedlings formation was also affected by $\mathrm{NaCl}$ presence in the medium, with a negative relationship between the number of seedling formed and $\mathrm{NaCl}$ concentration $(\mathrm{r}=-0.994)$. The effect of salt on seedling development was greater than that indicated for germination, confirming the higher salt tolerance of the embryo during the phase of germination as indicated above (Table 1).

Nevertheless, this general response to salt $(\mathrm{NaCl})$ of the in vitro olive embryo, there were difference among the embryos of each origin. Embryos from the two cultivated plants ("Galego" and "Lechín") growing in the World Olive plant Collection of Cordoba (Spain) in a non saline soil, presented lower germination and seedling formation than those from the plants growing in marshes and adapted to that harsh conditions (Cantos et al., 2002), but some embryos of the cultivated olive plants were able to form seedlings in the highest saline treatment and, on the contrary, some embryos of the plant growing in the salines soils dead in lower saline media. This behaviour showed the genetic variability of the olive embryo.

Root and stem seedling growth (Table 2) were also negatively affected by salt and as for percentage of germination and seedling formation, the embryos from salinised plants were less affected.

Addition of $\mathrm{NaCl}$ to the nutritive medium, also modified the nutrient composition of the seedlings, but in this case without differences between the different embryos considered. Then in Table 3, the nutritional status (as average of the different plantorigins) of the in vitro olive seedling-leaves, in relation to $\mathrm{NaCl}$ treatments is shown.

There were high accumulations of $\mathrm{Na}$ and $\mathrm{Cl}$, proportional to $\mathrm{NaCl}$ additions. Similar accumulations of $\mathrm{Na}$ and $\mathrm{Cl}$ were indicated by Downton (1977), Arbabzadeh \& Dutt (1987), and Troncoso et al. (1999), treating with $\mathrm{NaCl}$ other plant species cultured in vitro or by Royo \& Aragües (1989) for plants cultivated in green-house conditions. In coincidence with $\mathrm{Na}$ increase there was a decrease of $\mathrm{K}$. Antagonism between $\mathrm{K}$ and $\mathrm{Na}$ was indicated by García \& Charbaji (1989). The plants treated with $8 \mathrm{gL}^{-1} \mathrm{NaCl}$ showed 
higher contents of the remaining nutrients (Table 3) probably due to their lower development.

Salinity of the culture medium also affected the survival and growth of the in vitro explants (Tables 4 and 5). In coincidence with the results of the germination test, high saline conditions affected more the explants from cultivated trees than those from non cultivated salinised ones. Also, mortality caused by salt was higher in the non selected explants than in the selected ones. Then there was a relationship between the mother plant, its in vitro embryo-seedling and its in vitro explant with salt. It seems that the salttolerant ability of the origin plant was transmitted to its embryos and also to the plant material (explant) obtained from the germinated seedlings.

Explant growth was also negatively affected (inverse-relation) by salinity and, although conserving the same characteristics, the differences among explants groups were lower due to the selection process caused by mortality in the non selected explants.

As for seedling leaves, the nutritive status of the explant leaves was characterised by $\mathrm{Na}$ and $\mathrm{Cl}$ accumulations and $\mathrm{K}$ decreasing with salt concentration (Table 6). Then, these nutrient changes are good markers of the salinity conditions of the medium but did not establish differences among the embryos nor the explants compared.

In consequence, the mature olive embryo is a promising plant material for the in vitro selection of salt-tolerant olive clones due to: i) good in vitro response to germination and seedling formation, ii) relationship between mother plant characteristics and in vitro behaviour to salt of the corresponding embryo, seedling and explant, and iii) embryo genetic variability,

Also, due to the relationship between salt $(\mathrm{NaCl})$ concentration in the culture medium and $\mathrm{Na}$ and $\mathrm{Cl}$ content in the in vitro plant material, the levels of these saline elements are good markers of the salinity.

\section{References}

Acebedo M.M., Lavee S., Liñán J. and Troncoso A. 1997. In vitro germination of embryos for speeding up seedling development in olive breeding programmes. Sci. Hort., 69: 207-15.

Arbabzadeh F. and Dutt G. 1987. Salt tolerance of grape rootstock under greenhouse conditions. Am. J. Enol. Vitic., 38: 95-99.

Ben-Hayyim G., Vaadia, and Williams B.G. 1989. Proteins associated with salt adaptation in citrus and tomato cells: Involvement of $26 \mathrm{kDa}$ polypeptides. Physiol. Plant., 77: 332-340.

Bini G. and Bellini E. 1975. Influenza dei genitori sulla facoltà germinativa dei semi. Ricerche sull'olivo. Ortoflorofrutt. It., 59: 371-383.

Blackman S.A., Wettlaufer S.H., Obendorf R.L. and Leopold A.C. 1991. Maturation proteins associated with desiccation tolerance in soybean. Plant Physiol., 96: 868-874.

Cantos M., Troncoso J., Liñán J., Rapoport H. and Troncoso A. 2002. Obtaining salt $(\mathrm{NaCl})$ tolerant olive plants: i) some physiological and anatomical characteristics of olive plants growing in harsh saline zones. Acta Hortic., 586: 441-444.

Crisosto C. and Sutter G.E. 1985. Role of the endocarp in "Manzanillo" olive seed germination. J. Am. Soc. Hort. Sci., 110: 50-52.

Diamantoglou S. and Mitrakos.K. 1979. Sur la culture in vitro de l'embryon d'olivier (Olea europaea L. var. oleaster). C. R. Acad. Sci. París, Sér.D, 288:1537-1540.

Downton W.J.S. 1977. Photosynthesis in salt-stressed grapevines. Aust. J. Plant. Physiol., 4: 183-192. 
García M. and Charbaji T. 1993. Effect of sodium chloride salinity on cation equilibria in grapevine. J. Plant Nutr., 16: 2225-2237.

Garcia M.E., and Charbaji T. 1989. Influence de la teneur en chlorure de sodium du milieu sur la composition minerale de la vigne. Agrochimica, 33 (6): 412-423.

Lagarda A., Martín G.C. and Polito V.S. 1983. Anatomical and morphological development of 'Manzanillo' olive seed in relation to germination. J. Am. Soc. Hort. Sci., 108: 741-743.

Lambardi M., Rinaldi L.M.R., Memabeni D. and Cimato. A. 1994. Ethylene effect on in vitro olive seed germination (Olea europaea L.). Acta Hortic., 356: 54-57.

Mitrakos K. and Diamantoglou S. 1984. Endosperm dormancy breakage in olive seeds. Physio. Plant., 62 8-10.

Murashige T. and Skoog F. 1962. A revised medium for rapid growth and bioassays with tobacco tissue cultures. Plant Physiol., 15: 473-97.

Ried J.L and Walker-Simmons M.K. 1993. Group 3 late embryogenesis abundant proteins in desiccation-tolerant seedlings of wheat (Triticum aestivum L.). Plant Physiol., 102: 125-131

Royo A. and Aragües R. 1989. Efectos de la salinidad sobre las plantas: tolerancia, manejo agronómico, genética y mejora. Servicio de Investigación Agraria. Diputación General de Aragón. pp. 65

Rugini E. 1986. Olive (Olea europaea L). In: Biotechnology in agriculture and forestry. I. Trees, Y.P.S. Bajaj (Ed). Springer, Berlin, Germany, pp. 253-267.

Sarmiento R., Garcia J.L., Mazuelos C., Liñan J. and Troncoso A. 1994. Effect of the form and concentration of $\mathrm{N}$ on the growth and mineral composition of young olive seedlings. Acta Hortic., 356: 156-161.

Scaramuzzi F. and Baldini B. 1963. Olive da tavola. Edizioni Agricole. Bologna, Italy.

Skene K.G.M. and Barlass M. 1988. Response to $\mathrm{NaCl}$ of grapevine regenerated from multiple shoot cultures exhibiting mild salt tolerance in vitro. Am. J. Enol. Vitic, 39(2): 125-128.

Sotomayor-León E.M. and Caballero J.M. 1990. An easy method of breaking olive stones to remove mechanical dormancy. Acta Hortic., 206 113-116.

Thomas T.L. 1993. Gene expression during plant embryogenesis and germination - an overview. Plant Cell, 5: 1401-1410.

Troncoso A., Pérez A., Cantos M. and Liñán J. 1998. Germinación de semillas y embriones de olivo. Revista de Ciencias Agrarias. Vol. XXI n ${ }^{0}$ 1,2,3,4. Sociedad de Ciencias Agrarias de Portugal. Lisbon.

Troncoso A., Han N., García J.L. and Sarmiento R. 1991. Efecto de la concentración de Nitrógeno en el desarrollo de embriones de olivo "in vitro". Congreso. Consulation of the European Cooperative Research net-work on olive. Turquía. Bornova, Ishmir.

Troncoso A., Sarmiento R., García J.L., Mazuelos C. and Liñán J. 1994. Effect of the form and concentration of $\mathrm{N}$ on the growth and mineral composition of young olive seedlings. Acta Hortic.., 356: 156-161.

Troncoso A., Matte C., Cantos M. and Lavee S. 1999. Evaluation of salt tolerance in vitro-grown grapevine rootstock varieties. Vitis, 38 (2): 55-60.

Uniyal R.C. and Nautiyal A.R. 1998. Seed germination and seedling extension growth in Ougeinia dalbergioides Benth. under water and salinity stress. New-For., 16(3): 265272.

Voyiatzis D.G. and Pritsa T. 1994. The onset and disappearance of relative dormancy of olive embryos as affected by age. Acta Hortic., 356: 148-151. 
Voyiatzis D.G. 1995. Dormancy and germination of olive embryos as affected by temperature. Physiol. Plant., 95: 444-448.

Table 1. Influence of salinity $(\mathrm{NaCl})$ on germination and seedling formation of in vitro cultured olive embryos from 4 different plants.

\begin{tabular}{|l|c|c|c|c|c|c|c|c|}
\hline \multirow{3}{*}{$\begin{array}{c}\text { Embryo } \\
\text { from }\end{array}$} & 0 & 4 & 6 & 8 & 0 & 4 & 6 & 8 \\
\cline { 2 - 8 } & \multicolumn{6}{|c|}{$\%$ germination } & \multicolumn{5}{c|}{$\%$ seedling formation } \\
\hline Galego & $100^{\mathrm{bB}}$ & $100^{\mathrm{bB}}$ & $96^{\mathrm{bB}}$ & $55^{\mathrm{aA}}$ & $82^{\mathrm{dA}}$ & $75^{\mathrm{bA}}$ & $42^{\mathrm{bA}}$ & $5^{\mathrm{aA}}$ \\
Lechín & $100^{\mathrm{bB}}$ & $100^{\mathrm{bB}}$ & $96^{\mathrm{bB}}$ & $62^{\mathrm{aA}}$ & $88^{\mathrm{cA}}$ & $88^{\mathrm{cA}}$ & $56^{\mathrm{bA}}$ & $12^{\mathrm{aA}}$ \\
Raboconejo & $100^{\mathrm{bB}}$ & $100^{\mathrm{bB}}$ & $100^{\mathrm{bB}}$ & $80^{\mathrm{aB}}$ & $82^{\mathrm{cbA}}$ & $90^{\mathrm{dA}}$ & $68^{\mathrm{bBC}}$ & $32^{\mathrm{aB}}$ \\
Lagolargo & $100^{\mathrm{bB}}$ & $100^{\mathrm{bB}}$ & $100^{\mathrm{bB}}$ & $80^{\mathrm{aB}}$ & $88^{\mathrm{bA}}$ & $85^{\mathrm{bA}}$ & $70^{\mathrm{bC}}$ & $30^{\mathrm{aB}}$ \\
\hline
\end{tabular}

Different letters indicate significant differences (capital letters among clones, small letter among treatments) at $\mathrm{p} \leq 0.05$ level.

Table 2. Influence of salinity $(\mathrm{NaCl})$ on root and stem growth of in vitro olive seedlings from embryos of 4 different plants (60 days of culture).

\begin{tabular}{|l|c|c|c|c|c|c|c|c|}
\hline \multirow{2}{*}{$\begin{array}{c}\text { Embryo } \\
\text { from }\end{array}$} & \multicolumn{7}{|c|}{$\mathrm{gL}^{-1} \mathrm{NaCl}$} \\
\cline { 2 - 8 } & 0 & 4 & 6 & 8 & 0 & 4 & 6 & 8 \\
\cline { 2 - 8 } & \multicolumn{6}{|c|}{ Stem length (cm) } & \multicolumn{5}{c|}{ Root length $(\mathrm{cm})$} \\
\hline Galego & $2.5^{\mathrm{aA}}$ & $1.2^{\mathrm{aA}}$ & $1.2^{\mathrm{aA}}$ & $0.9^{\mathrm{aA}}$ & $13.0^{\mathrm{dA}}$ & $10.0^{\mathrm{cA}}$ & $6.0^{\mathrm{bA}}$ & $2.5^{\mathrm{aA}}$ \\
Lechín & $3.0^{\mathrm{aA}}$ & $2.5^{\mathrm{aA}}$ & $1.0^{\mathrm{aA}}$ & $0.7^{\mathrm{aA}}$ & $15.0^{\mathrm{dAB}}$ & $11.0^{\mathrm{cAB}}$ & $8.0^{\mathrm{bAB}}$ & $3.0^{\mathrm{aA}}$ \\
Raboconejo & $3.5^{\mathrm{aA}}$ & $3.0^{\mathrm{aA}}$ & $2.0^{\mathrm{aA}}$ & $1.0^{\mathrm{aA}}$ & $17.0^{\mathrm{cB}}$ & $12.5^{\mathrm{bB}}$ & $12.0^{\mathrm{bC}}$ & $8.0^{\mathrm{aB}}$ \\
Lagolargo & $4.0^{\mathrm{aA}}$ & $2.5^{\mathrm{aA}}$ & $2.0^{\mathrm{aA}}$ & $1.2^{\mathrm{aA}}$ & $16.0^{\mathrm{dB}}$ & $12.5^{\mathrm{bC}}$ & $10.0^{\mathrm{bB}}$ & $8.0^{\mathrm{aB}}$ \\
\hline
\end{tabular}

Different letters indicate significant differences (capital letters among clones, small letter among treatments) at $\mathrm{p} \leq 0.05$ level.

Table 3. Nutritional status of the in vitro olive seedling leaves in relation to the concentration of $\mathrm{NaCl}$ in the medium (average of the 4 original plants).

\begin{tabular}{|c|c|c|c|c|c|c|c|c|c|c|c|c|}
\hline \multicolumn{1}{|c|}{$\mathrm{NaCl}$} & \multicolumn{10}{c|}{$\% \mathrm{dm}$} & \multicolumn{4}{c|}{$\mathrm{ppm}$} \\
\hline $\mathrm{gL}^{-1}$ & $\mathrm{mM}$ & $\mathrm{N}$ & $\mathrm{P}$ & $\mathrm{K}$ & $\mathrm{Ca}$ & $\mathrm{Mg}$ & $\mathrm{Na}$ & $\mathrm{Cl}$ & $\mathrm{Fe}$ & $\mathrm{Mn}$ & $\mathrm{Zn}$ & $\mathrm{Cu}$ \\
\hline 0 & 0 & 4.71 & 0.49 & 2.21 & 0.50 & 0.13 & 0.63 & 0.68 & 293 & 179 & 150 & 25 \\
\hline 4 & 68 & 3.98 & 0.50 & 1.87 & 0.43 & 0.10 & 4.71 & 6.66 & 380 & 334 & 186 & 22 \\
\hline 6 & 103 & 4.48 & 0.53 & 1.67 & 0.44 & 0.09 & 5.96 & 7.72 & 520 & 249 & 225 & 27 \\
\hline 8 & 137 & 6.48 & 0.62 & 1.57 & 0.57 & 0.12 & 6.63 & 8.07 & 546 & 358 & 396 & 59 \\
\hline
\end{tabular}


Table 4. Influence of salinity on the survival after 60 days of in vitro culture of the non selected and selected olive explants.

\begin{tabular}{|c|c|c|c|c|c|c|c|c|}
\hline \multirow{2}{*}{$\begin{array}{l}\mathrm{gL}^{-1} \\
\mathrm{NaCl}\end{array}$} & \multicolumn{8}{|c|}{ SURVIVAL (\%) } \\
\hline & G-0 & $\mathrm{L}-0$ & $\mathrm{RC}-0$ & LL-0 & G-8 & L-8 & $\mathrm{RC}-8$ & LL-8 \\
\hline 0 & $100.0^{\mathrm{e}}$ & $100.0^{\mathrm{e}}$ & $100.0^{\mathrm{e}}$ & $100.0^{\mathrm{e}}$ & $100.0^{\mathrm{e}}$ & $100.0^{\mathrm{e}}$ & $100.0^{\mathrm{e}}$ & $100.0^{\mathrm{e}}$ \\
\hline 2 & $100.0^{\mathrm{e}}$ & $100.0^{\mathrm{e}}$ & $100.0^{\mathrm{e}}$ & $100.0^{\mathrm{e}}$ & $100.0^{\mathrm{e}}$ & $100.0^{\mathrm{e}}$ & $100.0^{\mathrm{e}}$ & $100.0^{\mathrm{e}}$ \\
\hline 4 & $97.9^{\mathrm{de}}$ & $95.8^{\mathrm{de}}$ & $100.0^{\mathrm{e}}$ & $100.0^{\mathrm{e}}$ & $100.0^{\mathrm{e}}$ & $100.0^{\mathrm{e}}$ & $100.0^{\mathrm{e}}$ & $100.0^{\mathrm{e}}$ \\
\hline 6 & $87.5^{\text {cde }}$ & $75.0^{\mathrm{abcd}}$ & $95.8^{\mathrm{de}}$ & $93.7^{\text {cde }}$ & $100.0^{\mathrm{e}}$ & $95.8^{\mathrm{de}}$ & $100.0^{\mathrm{e}}$ & $100.0^{\mathrm{e}}$ \\
\hline 8 & $85.4^{\text {bcde }}$ & $75.0^{\mathrm{abcd}}$ & $87.5^{\mathrm{cde}}$ & $93.7^{\text {cde }}$ & $95.8^{\mathrm{de}}$ & $100.0^{\mathrm{e}}$ & $100.0^{\mathrm{e}}$ & $95.8^{\mathrm{de}}$ \\
\hline 10 & $68.7^{\mathrm{ab}}$ & $68.7^{\mathrm{abc}}$ & $93.7^{\text {cde }}$ & $91.6^{\mathrm{cde}}$ & $100.0^{\mathrm{e}}$ & $97.9^{\mathrm{de}}$ & $100.0^{\mathrm{e}}$ & $100.0^{\mathrm{e}}$ \\
\hline 12 & $62.5^{\mathrm{ab}}$ & $54.1^{\mathrm{a}}$ & $85.4^{\text {bcde }}$ & $81.2^{\text {bcd }}$ & $91.6^{\text {cde }}$ & $91.6^{\text {cde }}$ & $100.0^{\mathrm{e}}$ & $95.8^{\mathrm{de}}$ \\
\hline
\end{tabular}

Different letters indicate significant differences at $\mathrm{p} \leq 0.05$ level.

Table 5. Influence of salinity on the growth after 60 days of in vitro culture of the non selected and selected olive explants.

\begin{tabular}{|c|c|c|c|c|c|c|c|c|}
\hline $\mathrm{gL}^{-1}$ & \multicolumn{7}{|c|}{ GROWTH $(\mathrm{mm})$} \\
\cline { 2 - 8 } $\mathrm{NaCl}$ & G-0 & L-0 & RC-0 & LL-0 & G-8 & L-8 & RC-8 & LL-8 \\
\hline 0 & $50^{\mathrm{a}}$ & $53^{\mathrm{a}}$ & $50^{\mathrm{a}}$ & $49^{\mathrm{a}}$ & $50^{\mathrm{a}}$ & $50^{\mathrm{a}}$ & $53^{\mathrm{a}}$ & $54^{\mathrm{a}}$ \\
2 & $52^{\mathrm{abcd}}$ & $40^{\mathrm{a}}$ & $48^{\mathrm{abc}}$ & $43^{\mathrm{ab}}$ & $52^{\mathrm{abc}}$ & $62^{\mathrm{cd}}$ & $55^{\mathrm{bcd}}$ & $64^{\mathrm{d}}$ \\
4 & $32^{\mathrm{b}}$ & $14^{\mathrm{a}}$ & $29^{\mathrm{b}}$ & $34^{\mathrm{b}}$ & $40^{\mathrm{bc}}$ & $35^{\mathrm{b}}$ & $40^{\mathrm{bc}}$ & $51^{\mathrm{c}}$ \\
6 & $15^{\mathrm{ab}}$ & $10^{\mathrm{a}}$ & $20^{\mathrm{bc}}$ & $23^{\mathrm{bc}}$ & $15^{\mathrm{ab}}$ & $15^{\mathrm{ab}}$ & $26^{\mathrm{c}}$ & $20^{\mathrm{abc}}$ \\
8 & $11^{\mathrm{b}}$ & $3^{\mathrm{a}}$ & $13^{\mathrm{bc}}$ & $9^{\mathrm{b}}$ & $10^{\mathrm{b}}$ & $8^{\mathrm{b}}$ & $16^{\mathrm{c}}$ & $9^{\mathrm{b}}$ \\
10 & $4^{\mathrm{b}}$ & $0^{\mathrm{a}}$ & $9^{\mathrm{c}}$ & $2^{\mathrm{ab}}$ & $2^{\mathrm{ab}}$ & $5^{\mathrm{bc}}$ & $16^{\mathrm{d}}$ & $3^{\mathrm{ab}}$ \\
12 & $1^{\mathrm{ab}}$ & $0^{\mathrm{a}}$ & $4^{\mathrm{bc}}$ & $0^{\mathrm{a}}$ & $5^{\mathrm{c}}$ & $5^{\mathrm{c}}$ & $15^{\mathrm{d}}$ & $3^{\mathrm{abc}}$ \\
\hline
\end{tabular}

Different letters indicate significant differences among varieties at $\mathrm{p} \leq 0.05$ level.

Table 6. Nutritional status of the in vitro olive explant leaves in relation to the concentration of $\mathrm{NaCl}$ in the medium (average of 4 original plants).

\begin{tabular}{|c|c|c|c|c|c|c|c|c|c|c|c|}
\hline $\mathrm{gL}^{-1}$ & \multicolumn{9}{|c|}{ \% d.m. } & \multicolumn{4}{c|}{$\mathrm{ppm}$} \\
\cline { 2 - 13 } $\mathrm{NaCl}$ & $\mathrm{N}$ & $\mathrm{P}$ & $\mathrm{K}$ & $\mathrm{Ca}$ & $\mathrm{Mg}$ & $\mathrm{Na}$ & $\mathrm{Cl}$ & $\mathrm{Cu}$ & $\mathrm{Fe}$ & $\mathrm{Mn}$ & $\mathrm{Zn}$ \\
\hline 0 & 2.05 & 0.31 & 3.48 & 0.97 & 0.55 & 0.40 & 1.97 & 6 & 74 & 249 & 114 \\
2 & 2.24 & 0.32 & 3.02 & 0.92 & 0.68 & 3.30 & 6.69 & 12 & 75 & 328 & 126 \\
4 & 2.80 & 0.48 & 2.70 & 0.63 & 0.47 & 4.57 & 7.11 & 9 & 53 & 176 & 104 \\
6 & 2.88 & 0.33 & 1.98 & 0.52 & 0.42 & 5.14 & 9.44 & 5 & 55 & 146 & 76 \\
8 & 2.41 & 0.49 & 1.92 & 0.62 & 0.53 & 7.95 & 10.46 & 17 & 49 & 170 & 120 \\
10 & 2.39 & 0.37 & 1.60 & 0.56 & 0.46 & 7.80 & 11.80 & 9 & 34 & 131 & 87 \\
\hline
\end{tabular}

